\title{
Role for leptin in promoting glucose mobilization during acute hyperosmotic stress in teleost fishes
}

\author{
David A Baltzegar, Benjamin J Reading, Jonathon D Douros and Russell J Borski \\ Department of Biological Sciences, North Carolina State University, Campus Box 7617, Raleigh, North Carolina
} 27695-7617, USA

Correspondence should be addressed to R J Borski

Email russell_borski@ncsu.edu

\begin{abstract}
Osmoregulation is critical for survival in all vertebrates, yet the endocrine regulation of this metabolically expensive process is not fully understood. Specifically, the function of leptin in the regulation of energy expenditure in fishes, and among ectotherms, in general, remains unresolved. In this study, we examined the effects of acute salinity transfer $(72 \mathrm{~h})$ and the effects of leptin and cortisol on plasma metabolites and hepatic energy reserves in the euryhaline fish, the tilapia (Oreochromis mossambicus). Transfer to 2/3 seawater (23 ppt) significantly increased plasma glucose, amino acid, and lactate levels relative to those in the control fish. Plasma glucose levels were positively correlated with amino acid levels $\left(R^{2}=0.614\right)$, but not with lactate levels. The mRNA expression of liver leptin A (lepa), leptin receptor (lepr), and hormone-sensitive and lipoprotein lipases ( $h s /$ and $I p /$ ) as well as triglyceride content increased during salinity transfer, but plasma free fatty acid and triglyceride levels remained unchanged. Both leptin and cortisol significantly increased plasma glucose levels in vivo, but only leptin decreased liver glycogen levels. Leptin decreased the expression of liver $h s /$ and $I p / m R N A s$, whereas cortisol significantly increased the expression of these lipases. These findings suggest that hepatic glucose mobilization into the blood following an acute salinity challenge involves both glycogenolysis, induced by leptin, and subsequent gluconeogenesis of free amino acids. This is the first study to report that teleost leptin A has actions that are functionally distinct from those described in mammals acting as a potent hyperglycemic factor during osmotic stress, possibly in synergism with cortisol. These results suggest that the function of leptin may have diverged during the evolution of vertebrates, possibly reflecting differences in metabolic regulation between poikilotherms and homeotherms.
\end{abstract}
Key Words
- osmoregulation
- leptin
- hyperglycemia
teleost fishes

Journal of Endocrinology (2014) 220, 61-72

\section{Introduction}

Teleost fishes are the largest group of vertebrates and are important models for understanding the endocrine and physiological mechanisms governing hydromineral balance (Evans et al. 2005). Euryhaline species have the remarkable ability to acutely withstand wide fluctuations in environmental salinity. During acute seawater (SW) acclimation, these animals overcome an increase in plasma osmolality of as much as $175 \mathrm{mOsm}$ through active excretion of ions, consuming $20-68 \%$ of their total metabolic energy demand (Morgan et al. 1997, Bœuf \& Payan 2001). The primary site of ion exchange is the gill (Evans et al. 2005), which has a low capacity for the

Published by Bioscientifica Ltd. 
oxidation of fatty acids or ketones (Segner et al. 1997, Crockett et al. 1999). Gill ionocytes utilize glucose from adjacent glycogen-rich cells (Tseng et al. 2007), and collectively the gill may represent only a fraction (3-8\%) of the energy demand (Morgan \& Iwama 1999), suggesting that other tissues contribute to the bulk of the expenditure (e.g. brain and kidney; Sangiao-Alvarellos et al. 2005, Polakof et al. 2006, Tseng \& Hwang 2008). Previous studies indicate that systemic mobilization of glucose, derived in part from the liver, is critical for meeting the energy requirements of acute salinity adaptation (Bashamohideen \& Parvatheswararao 1972, Chang et al. 2007).

The full complement of hormones regulating energy mobilization and expenditure in fishes is unclear, but it may differ to some degree from classic paradigms demonstrated in mammals. For example, glucose loading does not induce a subsequent period of hyperinsulinemia (Kelley 1993), and glucagon-like peptide 1 (GLP1), a hypoglycemic hormone in mammals, promotes hyperglycemia in fishes (Mommsen 2000). Similarly, cortisol promotes hyperglycemia through gluconeogenesis in fishes and mammals (Vijayan et al. 1996, Khani \& Tayek 2001), but it also promotes sodium excretion through the gill during SW adaptation (Evans et al. 2005). This steroid is lipolytic in vertebrates (Mommsen et al. 1999), yet no changes in plasma free fatty acid levels or lipid oxidation rates reportedly occur in salinity-challenged salmonids (Bystriansky et al. 2007).

The function and regulation of leptin in fishes, and among poikilotherms, in general, are also poorly understood. Leptin is an adipostatic cytokine exhibiting marginal hypoglycemic (Borba-Murad et al. 2004, Benomar et al. 2006) and strong lipolytic (Wang et al. 1999, Huang et al. 2006) effects in mammals. Plasma leptin levels are correlated with total fat stores in human subjects (Weigle et al. 1997) and decline during fasting while promoting satiety when high in rats and mice (Ahima \& Flier 2000), effects that remain unclear in non-mammalian vertebrates. In teleost fishes, the liver is considered to be the primary site of leptin production (Kurokawa \& Murashita 2009, Won et al. 2012), as opposed to adipose tissue in mammals, with current evidence suggesting that the hormone may suppress appetite (Won et al. 2012), but also paradoxically increases it during periods of fasting (Zhang et al. 2012; for a review, see Won \& Borski (2013)). Therefore, leptin may serve discrete roles of mobilizing energy during periods of stress or catabolism among vertebrate groups. Two leptin paralogs (lepa and lepb) exist in many teleosts, suggesting genome duplication as a potential mechanism of functional divergence (Gorissen et al. 2009, Kurokawa \& Murashita 2009, Zhang et al. 2012).
These studies aimed to evaluate the effects of an acute hyperosmotic challenge on plasma metabolites, hepatic energy reserves, and hepatic expression of leptin A and its receptor (lepr) in the euryhaline Mozambique tilapia (Oreochromis mossambicus) and the potential roles that leptin and cortisol may play in the regulation of elevated energy expenditure characteristic of this response. Newly developed recombinant tilapia leptin A (rtLepA) has been evaluated along with commercially prepared human leptin (recombinant human leptin (rhLep)) to assess potential differences in metabolic effect. Despite considerable divergence in peptide sequence ( $\sim 13 \%$ identity), the tertiary structures of human and fish leptins appear quite similar (Huising et al. 2006, Copeland et al. 2011), and mammalian forms have been commonly used to evaluate the function of leptin in teleost fishes (de Pedro et al. 2006, Gorissen et al. 2012, Won et al. 2012; see Won \& Borski (2013) for review). This study directly contrasts the effects of recombinant tilapia and human leptins, where many but not all responses appear to be conserved. Collectively, our findings suggest that the expression of tilapia leptin A is enhanced during SW adaptation and may function along with cortisol in the mobilization of glucose during acute periods of salinity stress.

\section{Materials and methods}

\section{SW challenge}

Adult male tilapia $(44 \pm 17 \mathrm{~g}$ mean body weight (BW)) were allowed to acclimate for 3 weeks in freshwater (FW; salinity $0-0.5 \mathrm{ppt}$, hardness $74-84 \mathrm{mg} / \mathrm{l}$, alkalinity $126-178 \mathrm{mg} / \mathrm{l}$, and $\mathrm{pH}$ 8.0) recirculating tank systems at $24-26^{\circ} \mathrm{C}$ with a photoperiod of $12 \mathrm{~h}$ light: $12 \mathrm{~h}$ darkness. The fish were fed $2 \%$ of their BW daily (40\% protein $/ 10 \%$ fat; Ziegler Brothers, Gardner, PA, USA). All the fish were treated in accordance with the North Carolina State University Institutional Animal Care and Use Committee. Acclimated fish were then transferred either to 23 ppt SW (Crystal Sea Salt Mix, Marine Enterprises, Baltimore, MD, USA) or to FW (sham transfer). The fish were fasted $24 \mathrm{~h}$ before the first sampling and for the duration of the challenge $(72 \mathrm{~h})$. Fish $(N=72 ; n=8$ fish/group) were sampled at $0,4,12,24$, and $72 \mathrm{~h}$ after transfer.

\section{Recombinant leptins}

The rhLep was purchased from Dr A F Parlow $(97 \pm 2 \%$ purity; National Hormone and Peptide Program, HarborUCLA Medical Center, Torrance, CA, USA).The rtLepA was

Published by Bioscientifica Ltd. 
produced using the Champion pET151 Directional TOPO Expression Kit (Life Technologies). Briefly, cDNA encoding the mature peptide sequence of Mozambique tilapia lepa (GenBank: KC354702) was cloned into an IPTG-inducible vector. The propagated cells were induced and lysed with a native isolation buffer for selective purification of free cytosolic proteins (kit-provided protocol), which were then purified by two rounds of double nickel-affinity chromatography (Life Technologies). The preparation was further purified by filter centrifugation ( $5000 \boldsymbol{g}$ for $15 \mathrm{~min}$ ) through Amicon Ultra protein purification columns with 30 and $10 \mathrm{kDa}$ molecular weight cutoffs (EMD Millipore, Billerica, MA, USA). The retained protein fraction was then dialyzed in $\mathrm{NaCO}_{3}$ for $4 \mathrm{~h}$ and lyophilized overnight. This method produced a single visible band of $16 \mathrm{kDa}$ (Supplementary Fig. 1A, see section on supplementary data given at the end of this article). The relative purity of rtLepA was determined by quantitative SDS-PAGE blot imaging (Odyssey Infrared Imager, LI-COR Biosciences, Lincoln, NE, USA) using Coomassie Fluor Orange Reagent (Invitrogen) and found to be $96.1 \%$ relative to that of the commercially prepared rhLep (Supplementary Fig. 1B). The bioactivity of the leptin(s) was evaluated in vitro using cultured hepatocytes from hybrid striped bass (Morone chrysops $\times M$. saxatilis). In cells incubated with $50 \mathrm{nM}$ human leptin, the mRNA expression of growth hormone receptor 1 ( $g h r 1)$ increased significantly after $24 \mathrm{~h}$ (Borski et al. 2011, Won 2012). In cells incubated with 5 and $50 \mathrm{nM}$ rtLepA, the mRNA expression of ghr1 increased after $18 \mathrm{~h}$, with the higher concentration leading to an eightfold elevation in gene expression (mean \pm s.E.M.; $0 \mathrm{nM}=1.00 \pm 0.51 ; \quad 5 \mathrm{nM}=2.70 \pm 0.80 ;$ and $50 \mathrm{nM}=$ $8.15 \pm 1.01 ; P<0.01$; data not shown), indicating that the rtLep produced is bioactive.

\section{Hormone injection studies}

Adult male tilapia ( $95 \pm 19 \mathrm{~g}$ mean BW) were allowed to acclimate for 3 weeks in recirculating tank systems (salinity 11-13 ppt, hardness 209-263 mg/l, alkalinity $127-152 \mathrm{mg} / \mathrm{l}$, and $\mathrm{pH} 7.5-8.0)$ and fed daily (2\% BW). The temperature and photoperiod regimens were the same as those described previously. Fishes were anesthetized using buffered MS-222 (Aquatic Eco-Systems, Apopka, FL, USA), weighed, and then administered one of the following i.p. injections: 0.5 or $5.0 \mu \mathrm{g} / \mathrm{g}$ BW of rhLep dissolved in PBS $\left(45 \mathrm{mM} \mathrm{NaCl}, 3 \mathrm{mM} \mathrm{Na} \mathrm{HPO}_{4}\right.$, and $0.6 \mathrm{mM} \mathrm{NaH} \mathrm{PO}_{4}, \mathrm{pH} 8.0$ and $329 \mathrm{mOsm}$ ); 0.5 or $5.0 \mu \mathrm{g} / \mathrm{g}$ BW of rtLepA (in PBS); or $10.0 \mu \mathrm{g} / \mathrm{g} \mathrm{BW}$ of cortisol in soybean oil (Sigma-Aldrich). Control fish were injected with either PBS or soybean oil (vehicle). Fish injected with cortisol and leptin were held in tanks that did not share a common water supply and were sampled at 6 and $24 \mathrm{~h}$ after injection $(N=112 ; n=8$ fish/group). Before the present experiment, a preliminary range-finding study was carried out to test the effects of three dosages of rtLepA $(1,10$, and $100 \mathrm{ng} / \mathrm{g}$ BW) and one dosage of rhLep (100 ng/g BW) on tilapia plasma glucose levels. None of these dosages elicited a response (Supplementary Fig. 2, see section on supplementary data given at the end of this article). Therefore, we tested the effects of higher hormone concentrations on metabolic parameters in this study, comparable to those levels previously shown to be effective for other cytokines to induce responses in tilapia (e.g. prolactin and GH; see Shepherd et al. (1997)).

\section{Sampling}

The fish were anesthetized using buffered MS-222, and blood was collected from the caudal vein using heparinized syringes. Plasma was separated by centrifugation $(3000 \boldsymbol{g})$ and stored at $-20^{\circ} \mathrm{C}$. Tissue samples were collected following decapitation. Gill and liver samples (100 mg) collected for RNA isolation were stored in $1 \mathrm{ml}$ of RNAlater (Life Technologies) and kept overnight at $4{ }^{\circ} \mathrm{C}$ before freezing $\left(-80^{\circ} \mathrm{C}\right)$. Liver $(50-100 \mathrm{mg})$ samples collected for glycogen and triglyceride assays were frozen in liquid $\mathrm{N}_{2}$. Liver samples $(50-100 \mathrm{mg}$ ) collected for alanine transaminase activity were immersed in $1 \mathrm{ml}$ of ice-cold SEI buffer ( $150 \mathrm{mM}$ sucrose, $50 \mathrm{mM}$ imidazole, $10 \mathrm{mM}$ EDTA, and $\mathrm{pH}$ 7.5) for $30 \mathrm{~min}$ before freezing $\left(\mathrm{N}_{2}\right)$.

\section{Assays}

Plasma osmolality was measured in duplicate with a VAPRO vapor pressure osmometer (WesCor, Logan, UT, USA). Metabolic assays were carried out using kit colorimetric reagents and protocols (Abcam, Cambridge, MA, USA) using an ELx800 microplate reader (BioTek Instruments, Winooski, VT, USA) fitted with 450 and $570 \mathrm{~nm}$ optical filters. Sample loading volumes were tested to ensure that they were within the standard curve range $\left(R^{2}=0.98-0.99\right)$. Specified background controls were utilized in each assay. Except for the following, assays were carried out in duplicate using $2-5 \mu \mathrm{l}$ of plasma.

Glycogen Liver samples were weighed before homogenization in $1.25 \mathrm{ml}$ of water and then boiled for $5 \mathrm{~min}$ and centrifuged $\left(13000 \boldsymbol{g}\right.$ at $4{ }^{\circ} \mathrm{C}$ for $\left.5 \mathrm{~min}\right)$.

Published by Bioscientifica Ltd. 
The supernatant ( $4 \mu \mathrm{l})$, diluted 1:25 in water, was used for the assay.

Triglycerides Liver samples were weighed and homogenized in $1 \mathrm{ml}$ of $5 \%$ Triton X-100. The homogenate was heated to $85^{\circ} \mathrm{C}$ and cooled twice before centrifugation. The supernatant (1-8 $\mu \mathrm{l})$ was used for the assay.

Alanine transaminase activity Liver samples were thawed on ice and residual SEI buffer was removed before weighing. The tissue samples were sonicated for $15 \mathrm{~s}$ in $250 \mu \mathrm{l}$ of ice-cold assay buffer and the homogenate was centrifuged (13 $000 \boldsymbol{g}$ at $4{ }^{\circ} \mathrm{C}$ for $10 \mathrm{~min}$ ). The supernatant $(2 \mu \mathrm{l})$ or a positive control was compared with a nonkinetic standard (1-12 nmol pyruvate) after the color had stabilized. The kinetic readings were taken at 1-min intervals for $60 \mathrm{~min}$, with a linear range observed from 11 to $19 \mathrm{~min}$.

Free fatty acids Long-chain fatty acids (C-8 or greater) were detected $\left(\mathrm{OD}_{570} \mathrm{~nm}\right)$ by enzymatic production and oxidation of acyl-CoA derivatives (free fatty acid quantification kit; Abcam). Neat plasma samples of $30 \mu \mathrm{l}$ were assayed in duplicate with a negative control (containing no acyl-CoA synthetase) used for background corrections. Values were determined using a palmitic acid standard curve (1-10 nmol).

\section{Gene expression}

Total RNA was isolated from gill and liver tissue samples using TRI Reagent (Molecular Research Center, Cincinnati, $\mathrm{OH}, \mathrm{USA})$, coupled with column affinity purification and DNAse treatment using Direct-zol minipreps (Zymo Research, Irvine, CA, USA). RNA quality was assessed by $18 \mathrm{~S}$ and $28 \mathrm{~S}$ rRNA integrity and $\mathrm{OD}_{260: 280}$ ratios (range 1.9-2.0). Total RNA (1.25 $\mu \mathrm{g})$ was reverse-transcribed using random hexamers (High Capacity cDNA Synthesis, Life Technologies). The mRNA expression of the following genes was then measured by real-time quantitative PCR: gill - atpa $1 a$ and atpa $1 b$; liver - hsl, lepa, lepr, lipe, and lpl; and both gill and liver - glucose transporter 1 (glut1), glut4-l, and pyg. All primers, except atpa1a and atpa1b (see Tipsmark et al. (2011)), were designed using ABI Primer Express (v3.0), and they are listed out in Supplementary Table 1 , see section on supplementary data given at the end of this article, along with measurements of PCR efficiency calculated using the LinReg analysis of the log (fluorescence) amplification curves (Ramakers et al. 2003). The mean efficiency range for all the qPCRs was
95.8-105.3\%. Assays were carried out using 12-25 ng of cDNA template and $75 \mathrm{nM}$ primer concentrations with Brilliant II SYBR Green Master Mix (Agilent, Santa Clara, CA, USA). Triplicate runs for all the samples, standards, and negative controls were performed on an ABI 7900HT sequence detection system. Pooled cDNA samples were used for across-plate normalization with negative controls run on each plate. Cycle threshold $(C t)$ values were analyzed by absolute quantification using standard curves derived from serially diluted cDNA for each tissue $\left(R^{2}=0.98-0.99\right)$. Data were then normalized to the expression of $\beta$-actin (bactin1). The suitability of bactin1 as a reference gene for osmoregulatory studies has previously been established through studies in the gill (Velan et al. 2011) and liver (Deane et al. 2002) of teleost fishes and further verified in the present study by normalization to total RNA (Bustin 2000). We found little change in the expression of this housekeeping gene in the present study among the treatment groups. The mean difference in fold change $(\Delta \mathrm{fc})$ for the treatment effects was 0.42 for the salinity challenge and 0.20 for the hormone injection studies. For the salinity challenge, values are expressed as relative fold change to the mean of the initial $\left(\mathrm{T}_{0}\right)$ group (calibrator). For the injection studies, values are expressed as relative fold change to the mean of the 6-h control. Specific amplification of these genes was verified by melting-curve profile and gel electrophoresis.

\section{Statistical analyses}

All the analyses were carried out using the JMP Software (v9, SAS Institute, Cary, NC, USA). A two-way factorial ANOVA was employed for the salinity challenge, followed by Tukey's honestly significant difference (HSD) post hoc test if the model was significant. Initial $\left(\mathrm{T}_{0}\right)$ fish were treated as both a FW control and SW challenge group for statistical purposes. Linear correlations of plasma glucose were performed separately for each treatment group using a bivariate analysis. A one-way ANOVA was employed for the hormone injection studies, followed by post hoc testing against control groups using Dunnett's test. The nominal level for significance for all the tests was $P<0.05$.

\section{Results}

\section{SW challenge}

FW tilapia were challenged with $2 / 3 \mathrm{SW}$ (23 ppt) or with FW for $72 \mathrm{~h}$. The plasma osmolality of the SW fish increased by $4 \mathrm{~h}$ and reached a maximum value of

Published by Bioscientifica Ltd. 
$475 \mathrm{mOsm} / \mathrm{kg}$ by $24 \mathrm{~h}(P<0.001$; Fig. 1A). The osmolality levels subsequently declined by $72 \mathrm{~h}$, but were significantly elevated compared with those of FW fish $(325 \mathrm{mOsm} / \mathrm{kg} ; P<0.001)$. The expression of the gill SWtype $\mathrm{Na}^{+}, \mathrm{K}^{+}$-ATPase $\alpha$-subunit (atpa1b) increased after
$12 \mathrm{~h}$ and remained significantly elevated $(P<0.001$; Fig. 1B). By contrast, the expression of the gill FW isoform (atpa1a) decreased significantly by $12 \mathrm{~h}(P<0.001)$ in SW fish, but it did not differ from that of FW fish at later time points (Fig. 1C).
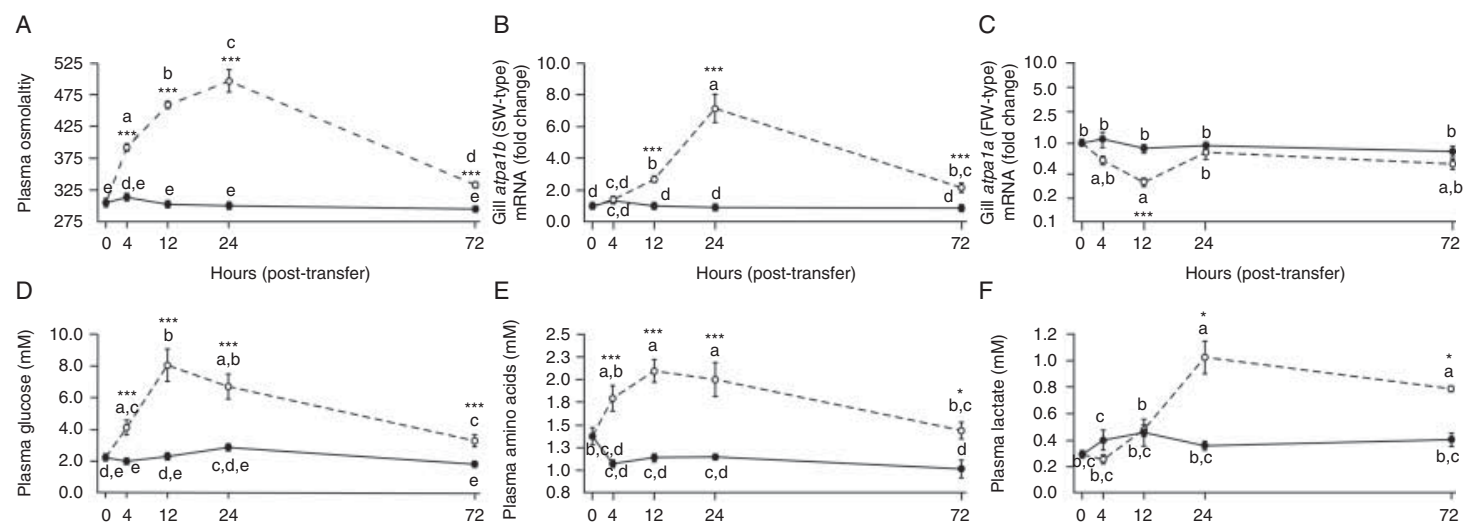

G
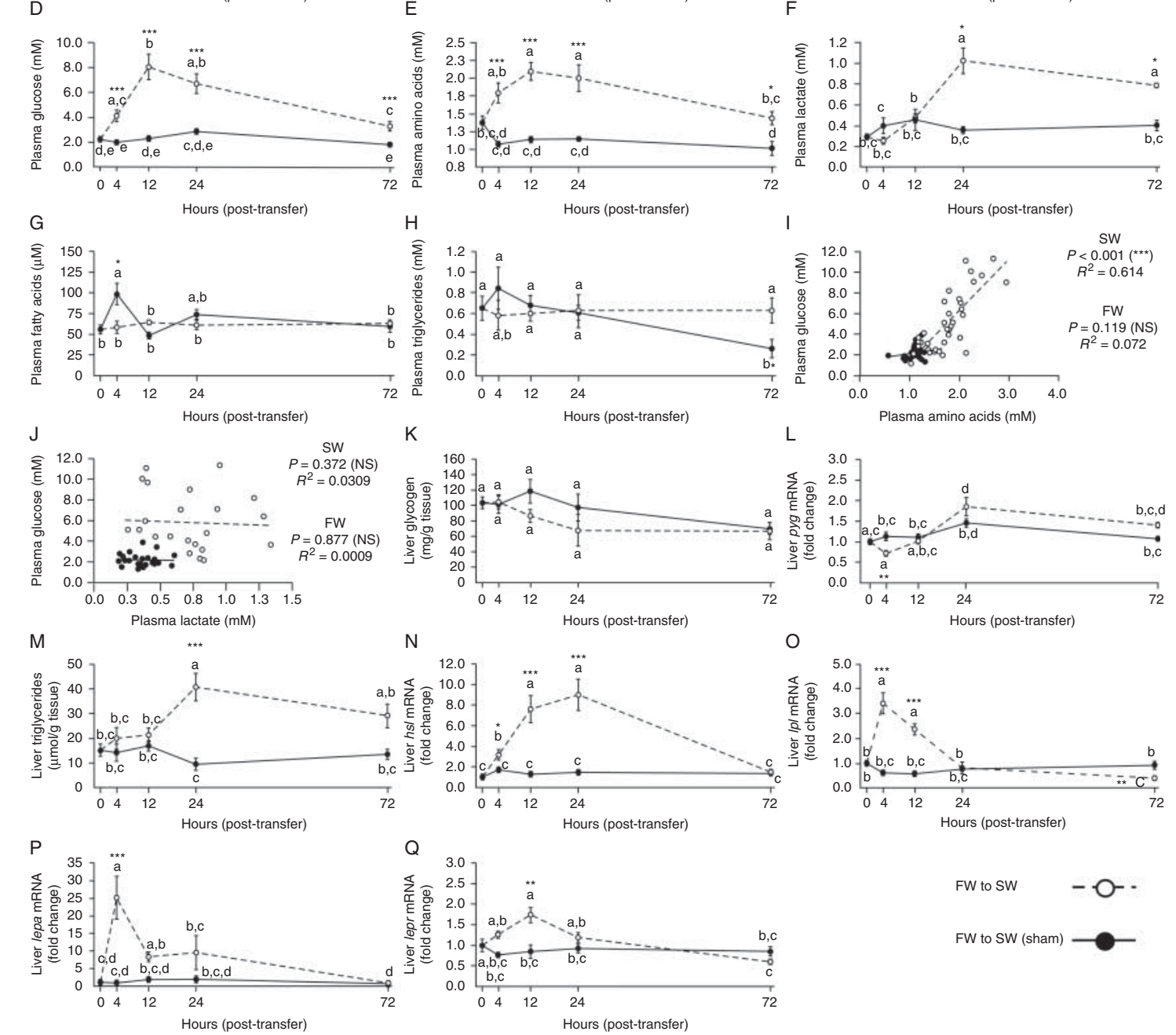

\section{Figure 1}

Effects of SW transfer on tilapia (A) plasma osmolality, (B) gill SW-type ATPase (atpa1b) mRNA expression, (C) gill freshwater (FW)-type ATPase (atpa1a) mRNA expression, plasma (D) glucose content, (E) amino acid content, (F) lactate content, (G) free fatty acid content, and (H) triglyceride content. (I and J) Bivariate correlations between plasma glucose levels and (I) amino acid and (J) lactate levels. Effects of SW transfer on hepatic (K) glycogen content, (L) glycogen phosphorylase (pyg) mRNA expression, $(\mathrm{M})$ triglyceride content, $(\mathrm{N})$ hormone-sensitive lipase (hsl) mRNA expression, (O) lipoprotein lipase (IpI) mRNA expression, (P) leptin A (lepa) mRNA expression, and (Q) leptin receptor (lepr) mRNA expression. Asterisks indicate time-dependent effects relative to those in the FW fish (***P<0.001, **P<0.01, and $* P<0.05$; ANOVA); letters indicate effects across time $(P<0.05)$. Expression data are shown as fold change relative to $\mathrm{T}_{0}$ fish. Except for amino acid and lactate levels ( $\mathrm{I}$ and $\mathrm{J}$ ), data represent means \pm S.E.M. ( $n=5-8$ fish/group). http://joe.endocrinology-journals.org DOI: 10.1530/JOE-13-0292
(C) 2014 Society for Endocrinology Printed in Great Britain
Published by Bioscientifica Ltd. 


\section{Plasma metabolites}

Plasma glucose levels were significantly higher in the SW fish following transfer $(P<0.05$; Fig. 1D), reaching $8 \mathrm{mM}$ $(P<0.001)$ by $12 \mathrm{~h}$ and declining to $4 \mathrm{mM}$ by $72 \mathrm{~h}$ $(P<0.05)$. Plasma amino acid levels were also significantly higher in SW fish after transfer $(P<0.05$; Fig. 1E), reaching maximum values at $12 \mathrm{~h}(2 \mathrm{mM})$ and then declining. Mean plasma lactate levels were significantly higher from 24 to $72 \mathrm{~h}$ in the SW fish $(P<0.01$; Fig. $1 \mathrm{~F})$. Non-esterified (free) fatty acid levels in SW fish were not different from $\mathrm{T}_{0}$ levels at any time; however, levels were significantly higher in the FW fish at $4 \mathrm{~h} \quad(P<0.05$; Fig. 1G). Plasma triglyceride levels in SW fish did not differ from $\mathrm{T}_{0}$ levels, but in $\mathrm{FW}$ fish the levels decreased from 4 to $72 \mathrm{~h}$ and were significantly lower than those in the SW fish by $72 \mathrm{~h}(P<0.05$; Fig. $1 \mathrm{H})$. Plasma amino acid and lactate levels were correlated with plasma glucose levels (Fig. 1I and J). No significant correlation with plasma glucose was observed for plasma amino acids $\left(R^{2}=0.072\right)$ or lactate $\left(R^{2}=0.0009\right)$ for fish transferred to FW. A positive correlation was observed between glucose and amino acid levels in SW-challenged fish (slope $>0$; $R^{2}=0.614 ; P<0.001 ;$ Fig. 1I). No significant correlation was observed for lactate levels in the SW fishes $\left(R^{2}=0.0309\right.$; Fig. 1J).

\section{Liver catabolism}

Liver glycogen levels in SW fish were lower from 12 to $24 \mathrm{~h}$, but did not differ significantly (Fig. 1K). The expression of liver glycogen phosphorylase ( $p y g)$ mRNA in SW fish was significantly lower at $4 \mathrm{~h}(P<0.01)$, but did not differ from that of FW fish at later time points (Fig. 1L). In SW fish, liver triglyceride levels rose sharply at $24 \mathrm{~h}(P<0.001)$ and declined by $72 \mathrm{~h}$ (Fig. 1M). The expression of liver hormone-sensitive lipase ( $h s l$ ) mRNA was significantly elevated in SW fish from 4 to $24 \mathrm{~h}$ $(P<0.05-0.001)$ and then declined by $72 \mathrm{~h}$ (Fig. $1 \mathrm{~N})$. The expression of liver lipoprotein lipase $(l p l)$ mRNA in the SW fish was significantly higher at 4 and $12 \mathrm{~h}(P<0.001)$, but it declined and was significantly lower than that of FW fishes by $72 \mathrm{~h}(P<0.01$; Fig. 1O). The expression of liver leptin A (lepa) mRNA in the SW fish increased 25-fold after $4 \mathrm{~h}(P<0.001)$ and then declined from 12 to $24 \mathrm{~h}$, but remained elevated with respect to that of FW fish (Fig. 1P). The expression of lepr mRNA increased by $4 \mathrm{~h}$ and was significantly higher after $12 \mathrm{~h}$ in SW fish $(P<0.01)$ and then returned to control levels (Fig. 1Q).

\section{Effects of leptin and cortisol}

rtLepA and rhLep were tested with cortisol 6 and $24 \mathrm{~h}$ after injection. Both hormones increased plasma glucose levels at $6 \mathrm{~h}$ at the high dosage $(5.0 \mu \mathrm{g} / \mathrm{g} \mathrm{BW} ; P<0.05)$, but only rhLep exerted significant effects at the low dosage $(0.5 \mu \mathrm{g} / \mathrm{g}$ BW; $P<0.01$; Fig. $2 \mathrm{~A})$. At $24 \mathrm{~h}$, only rhLep (low dose) increased glucose levels $(P<0.05$; Fig. $2 \mathrm{~A})$. The cortisol-injected fish had significantly higher glucose

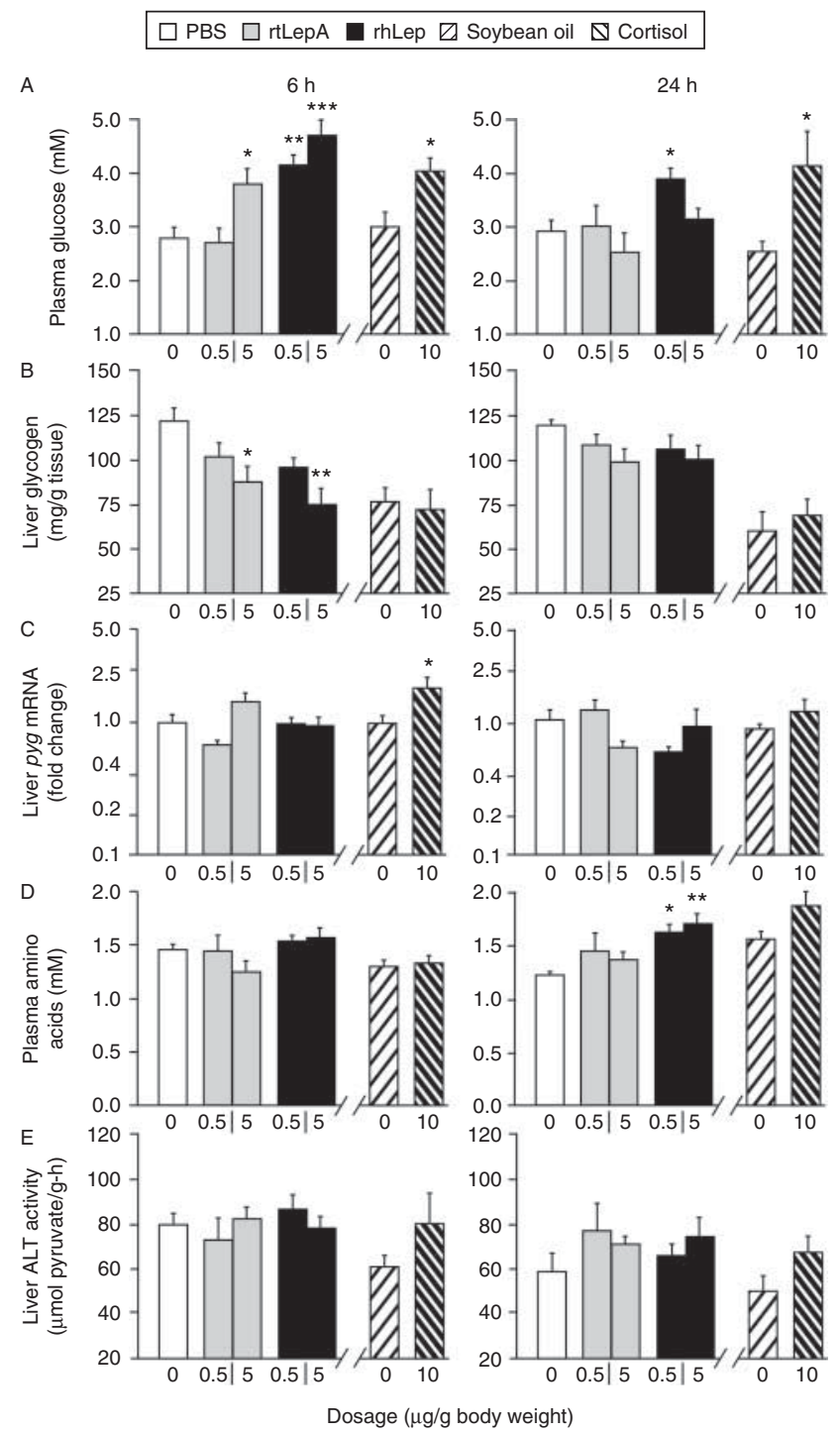

Figure 2

Effect of leptin and cortisol injection (6 and $24 \mathrm{~h}$ ) on tilapia (A) plasma glucose content, (B) liver glycogen content, (C) liver glycogen phosphorylase mRNA expression, (D) plasma amino acid content, and (E) liver alanine transaminase (ALT) activity. Asterisks indicate significant effects against the control ( $* * * P<0.001, * * P<0.01$, and $* P<0.05$; ANOVA). Expression data are shown as fold change relative to 6 -h controls. Data represent means \pm s.E.M. ( $n=5-8$ fish/group).

Published by Bioscientifica Ltd. 
levels at 6 and $24 \mathrm{~h}(P<0.05$; Fig. 2A). Both leptins decreased liver glycogen levels by $6 \mathrm{~h}(P<0.05)$, but the levels were not different at $24 \mathrm{~h}$ (Fig. 2B). No significant differences in liver glycogen levels were observed in the cortisol-injected fish (Fig. 2B). The expression of liver $p y g$ mRNA did not differ significantly in leptin-injected fish (6 or $24 \mathrm{~h}$ ), but the cortisol-injected fish exhibited significantly higher expression of pyg mRNA at $6 \mathrm{~h}$ $(P<0.05)$, but not at $24 \mathrm{~h}$ (Fig. 2C). Plasma amino acid levels remained unchanged $6 \mathrm{~h}$ after leptin or cortisol injection, but they were significantly higher after rhLep injection by $24 \mathrm{~h}(P<0.01-0.05$; Fig. $2 \mathrm{D})$. Liver alanine transaminase activity remained unchanged after either leptin or cortisol injection (Fig. 2E).

Mean liver triglyceride levels were significantly higher $(P<0.05)$ in the rhLep-injected fish (high dose) after $6 \mathrm{~h}$ relative to those in the control fish (Fig. 3A). No difference in triglyceride levels was observed at 6 or $24 \mathrm{~h}$ after cortisol injection (Fig. 3A). The expression of liver hsl mRNA declined twofold by $6 \mathrm{~h}$ following low-dose rtLepA administration $(P<0.05$; Fig. 3B). The cortisol-injected fishes exhibited significantly higher expression of $h s l$ mRNA relative to the control fish at $6 \mathrm{~h} \quad(P<0.01$; Fig. 3B). By $24 \mathrm{~h}$, no significant changes were observed in the expression of hsl mRNA with either hormone injection (Fig. 3B). The expression of liver $l p l$ mRNA was significantly lower at $6 \mathrm{~h}$ at both doses of rtLepA $(P<0.01)$, and it remained lower in the low-dose rtLepA-injected fish at $24 \mathrm{~h}(P<0.05$; Fig. 3C). The cortisol-injected fish exhibited higher expression of $l p l$ mRNA at $6 \mathrm{~h}$ relative to the control fish $(P<0.05$; Fig. 3C). The expression of liver lepr mRNA in the rtLepA-injected fish was lower by $6 \mathrm{~h}$ (low dose; $P<0.001$ ), but not at $24 \mathrm{~h}$ (Fig. 3D). Cortisol increased the expression of lepr mRNA by $6 \mathrm{~h}(P<0.01)$, but no difference was observed at $24 \mathrm{~h}$ (Fig. 3D). Neither leptin nor cortisol administration significantly affected the expression of liver lepa mRNA (Supplementary Fig. 3A, see section on supplementary data given at the end of this article). Both doses of rtLepA significantly decreased the expression of liver glut1 mRNA relative to that in the control fishes at $6 \mathrm{~h}(P<0.05)$, but not at $24 \mathrm{~h}$ (Fig. 3E). Cortisol increased the expression of glut1 mRNA by $6 \mathrm{~h}$ $(P<0.01)$, but not at $24 \mathrm{~h}$ (Fig. $3 \mathrm{E})$.

\section{Discussion}

The hormonal components of energy mobilization during osmotic stress remain elusive, despite significant contributions to osmoregulatory physiology (Evans et al. 2005, Tseng \& Hwang 2008). In this study, the SW-challenged fish had significantly higher plasma glucose levels, observed maximally $12 \mathrm{~h}$ after transfer and before peak increases in plasma osmolality and gill ATPase mRNA expression (Fig. 1A, B and D). Parallel changes in plasma free fatty acid or triglyceride levels were not observed (Fig. 1G and H). These findings are in agreement with historical reports of enhanced glucose utilization during osmotic stress (Bashamohideen \& Parvatheswararao 1972, Fiess et al. 2007). Concomitantly, we observed a 25 -fold increase in the expression of liver lepa mRNA in the SW fish at $4 \mathrm{~h}$, followed by an elevation in the expression of lepr mRNA after

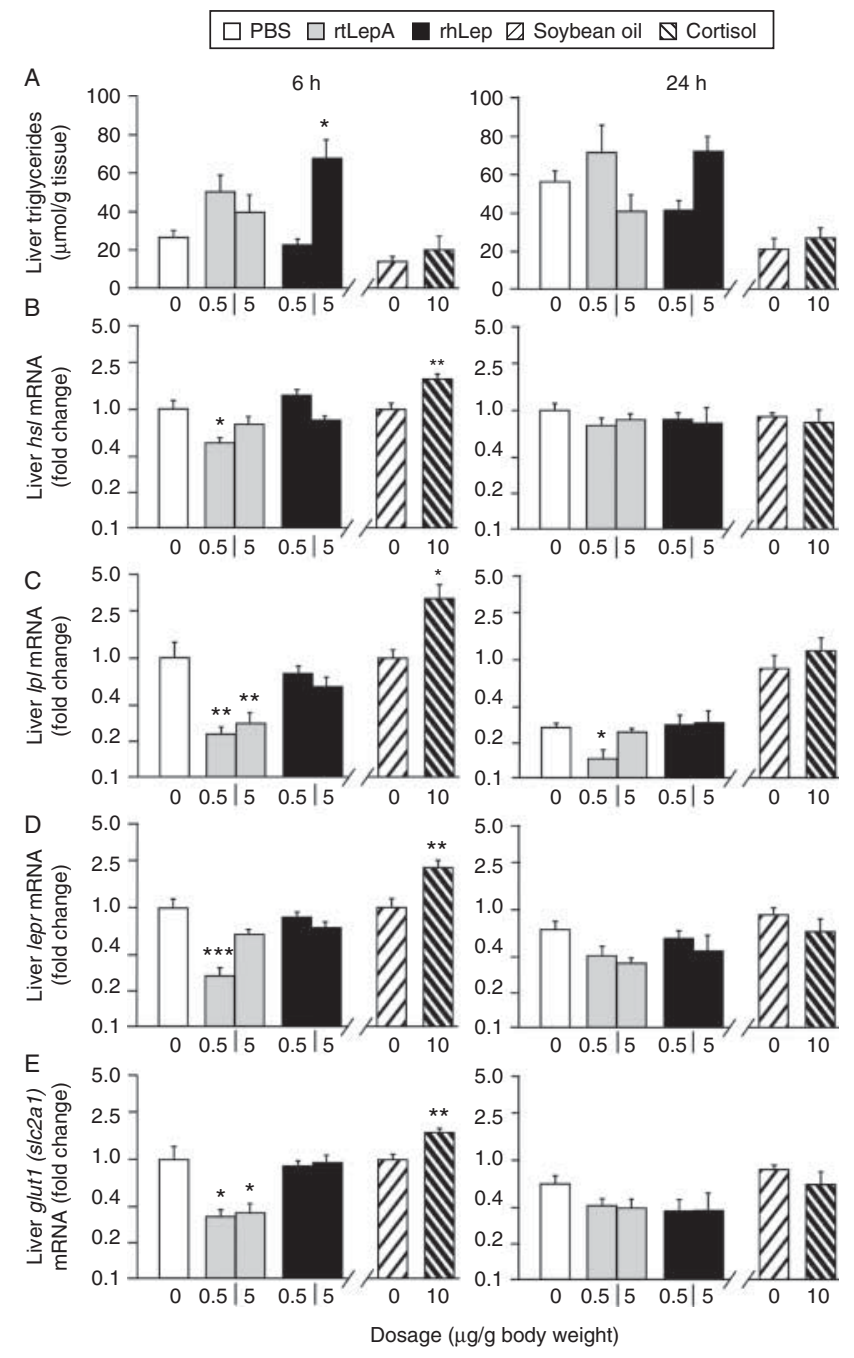

Figure 3

Effect of leptin and cortisol injection (6 and $24 \mathrm{~h}$ ) on tilapia liver (A) triglyceride content, $(B)$ hormone-sensitive lipase mRNA expression, (C) lipoprotein lipase mRNA expression, (D) leptin receptor mRNA expression, and (E) glucose transporter 1 (glut1) mRNA expression. Asterisks indicate significant effects against the control $(* * * P<0.001$, $* * P<0.01$, and $* P<0.05$; ANOVA). Expression data shown as fold change relative to 6 -h controls. Data represent means \pm s.E.M. ( $n=5-8$ fish/group).

Published by Bioscientifica Ltd. 
$12 \mathrm{~h}$ (Fig. 1P and Q). These novel findings of lepa sensitivity to hyperosmotic perturbation, along with results demonstrating hyperglycemia (Fig. 2A), suggest that tilapia leptin A functions in the mobilization of glucose to meet the energy demands of SW adaptation and possibly other catabolic stressors, such as fasting and hypoxia (Bernier et al. 2012, Gorissen et al. 2012).

In previous work, liver glycogen levels have been found to decline in the first $12 \mathrm{~h}$ of a SW challenge in tilapia, with sparing occurring thereafter (Chang et al. 2007). We found that liver glycogen levels decreased, but not significantly, compared with those of control fish (Fig. 1K). As a decline in glycogen levels was also observed in the control group, short-term fasting may have masked the detection of a significant salinity effect (Fig. 1K). Nevertheless, we observed a significant increase in plasma glucose levels in fish injected with the high dose of rtLepA (Fig. 2A), similar to observations made during the salinity challenge. Elevated plasma glucose levels were accompanied by significant decreases in liver glycogen levels (Fig. 2B), suggesting that this hormone induces hepatic glycogenolysis. A similar action has been proposed for leptin in lizards (Podarcis sicula; Paolucci et al. 2006), suggesting functional conservation in other poikilotherms. Furthermore, leptin A downregulated the expression of liver glut1 mRNA (Fig. 3E) and, to a lesser extent, that of glut4-like mRNA (Supplementary Fig. 3B), but neither changed in the gill (Supplementary Fig. 3C and D), suggesting that the hormone reduces hepatic glucose uptake. In contrast to what is observed in mammals, our findings identify teleost leptin $\mathrm{A}$ as a novel hyperglycemic factor critical for meeting the energy requirements of SW adaptation. Although circulating leptin A levels were not measured due to lack of homologous antisera, previous studies in fishes have shown that increases in the expression of liver lepa during fasting correlate with circulating hormone titer (Trombley et al. 2012). The liver is the primary site for leptin A production in perciform fishes and hence the source of circulating hormone (Won et al. 2012). The rise in the expression of lepr during SW acclimation (Fig. 1Q) also suggests that the paracrine effects of leptin signaling are enhanced through greater sensitivity in the liver.

The mechanism(s) by which leptin promotes glycogenolysis or is responsive to salinity is unclear. Leptin reduced liver glycogen levels without appreciable changes in the expression of pyg mRNA (Fig. 2C). As this enzyme is rate limiting in glycogen catabolism (Tseng et al. 2007), we hypothesize that leptin A may act in a paracrine fashion to exert effect(s) on the activity of this enzyme and/or may operate through the induction of other factors, including GLP1 (Mommsen 2000), catecholamines (Takekoshi et al. 2001), and glucagon. A sympathetic response has been postulated as a mediator for leptin in the regulation of 'glucose sensing' in the brain of rainbow trout (Oncorhynchus mykiss; Aguilar et al. 2010). As neither homologous nor heterologous leptin appears to alter gill pyg mRNA, gill ATPase mRNA, or plasma osmolality levels (Supplementary Fig. 3E, F, G and H), the actions of leptin may be limited to the regulation of systemic energy expenditure during osmoregulation. Future studies are required to assess other potential effects of leptin on hydromineral balance, as well as factors responsive to ionic perturbation (e.g. osmotic pressure and osmoregulatory hormones), which may enhance leptin production during SW adaptation.

Leptin is adipostatic in mammals, promoting lipolysis through oxidative metabolism in the liver and adipose tissue and inhibiting hepatic very low density lipoprotein (VLDL) secretion (Wang et al. 1999, Ahima \& Flier 2000, Huang et al. 2006). However, there is no clear evidence that this hormone induces lipolysis in fishes (Li et al. 2010, Copeland et al. 2011, Liu et al. 2012). We found little or no effects on lipid catabolism in this study. Human leptin increased liver triglyceride levels, and the expression of lipase mRNAs ( $h s l$ and $l p l$ ) was reduced by as much as $50 \%$ in fishes injected with homologous hormone (Fig. 3A, B and $\mathrm{C}$ ). Furthermore, liver triglyceride levels were increased in SW-challenged fish, while plasma triglyceride and free fatty acid levels remained unchanged when the expression of liver lepa mRNA was elevated (Fig. 1G, H, M and $\mathrm{P}$ ). This is more consistent with a marginal lipogenic response, rather than with a lipolytic one, suggesting that leptin A may have a function that is distinct from that of mammals in regulating carbohydrate and lipid energy reserves. Factors that may have led to this divergence could include partial or complete neofunctionalization of leptin A relative to leptin $\mathrm{B}$, the function of which is yet to be evaluated (Gorissen et al. 2009, Kurokawa \& Murashita 2009), or the inherent differences in the energy requirements and metabolic regulation between homeotherms and poikilotherms (Paolucci et al. 2006). If the effects of leptin B, newly identified in the tilapia genome, are found to be different from those of leptin A, then the derived and ancestral functions of this hormone may be further elucidated, which will be important for understanding the evolution of energy balance in vertebrates.

Commercially prepared rhLep is commonly used for comparative studies in teleosts (Tipsmark et al. 2008,

Published by Bioscientifica Ltd. 
Gorissen et al. 2012, Won et al. 2012). In particular, in vivo administration of rhLep has been shown to decrease appetite in fishes, a classic effect of leptin in mammals (Ahima \& Flier 2000, Won et al. 2012). The development of rtLepA provided the opportunity to functionally contrast the effects of both human and homologous forms in our experimental design. Interestingly, we found consistent responses, such as those observed for plasma glucose and liver glycogen content (Fig. 2A and B), for the two hormones, but also observed effects that were quite distinct. rtLep regulated the expression of liver lipases ( $h s l, l p l)$, lepr, and glut1 mRNAs, while rhLep was altogether ineffective on these parameters (Fig. 3B, C, D and E). It is unlikely that any of the disparities between the responses for tilapia and human leptin reflect differences in hormone purity, and hence effective dosage, as our rtLepA preparation was $96 \%$ pure, only $4 \%$ lower than that of commercial rhLep (Supplementary Fig. 1A and B). The mechanism(s) by which some responses for tilapia and human leptin are shared, while others appear divergent, is unclear, but may include differences in receptor binding or cell signaling, perhaps further pointing toward potential sub- or neofunctionalization of leptin paralogs (leptin A and B) in fishes. Regardless of this, our results suggest that while heterologous hormone may be useful in some instances, homologous or closely related forms are probably better for discriminating the potential scope of physiological actions of leptin in fishes.

Hepatic gluconeogenesis has been examined only recently during early SW adaptation, despite historical reports of elevated nitrogen excretion rates (Evans et al. 2005, Bystriansky et al. 2007, Aragão et al. 2010). This is probably due to two factors: i) free amino acids were thought to act as solutes to counter osmotic forces (Tseng \& Hwang 2008) and ii) decreases in glycogen pointed to glycogenolysis as the source of glucose (Bashamohideen \& Parvatheswararao 1972, Chang et al. 2007). In the present study, the levels of plasma free amino acids and lactate, substrates for gluconeogenesis, were elevated in the blood of the SW tilapia (Fig. 1E and F), but only amino acid levels were correlated with glucose levels (Fig. 1I and J). Moreover, our findings and the work of others show that declines in glycogen levels stabilize $12-24 \mathrm{~h}$ after SW transfer (Fig. 1K; also Chang et al. (2007)), despite elevated glucose, amino acid, and lactate levels beyond this period (Fig. 1D, E and F). Sustained exposure to SW has been shown to increase the activity of hepatic transaminases in Gilthead seabream (Sparus aurata), enzymes that are mediators of gluconeogenesis (Polakof et al. 2006). This finding and the present data suggest that gluconeogenic conversion of amino acids may augment blood glucose levels during later periods ( $>12-24 \mathrm{~h}$ ) of salinity acclimation (Fig. 4). The conversion of free amino acids by the liver may also explain, in part, the paradoxical rise in liver triglyceride levels in SW-challenged fish. Liver triglyceride levels doubled after $24 \mathrm{~h}$ (Fig. 1M), suggesting increased rates of fatty acid synthesis and lipogenesis. The accumulation of acetyl-CoA (fatty acid precursor), through the catabolism of ketogenic amino acids, may explain this effect (Jürss \& Bastrop 1995; Fig. 4), as increases in plasma levels of the ketogenic amino acids leucine and isoleucine have been reported in SW-challenged Arctic char (Salvelinus alpinus; Bystriansky et al. 2007). Thus, in addition to exerting an osmotic effect, SW-induced aminoacidemia may provide a mechanism for de novo synthesis of both carbohydrates and lipids.

We evaluated whether leptin and cortisol might alter metabolites in a manner reflective of gluconeogenesis. Previous studies have shown elevated cortisol levels in the blood of teleosts during salinity adaptation (Evans et al. 2005). In Mozambique tilapia challenged with $2 / 3$ SW (20-25 ppt), plasma cortisol levels (Kammerer et al. 2010) and tissue sensitivity (glucocorticoid receptor; see Dean et al. (2003) and Aruna et al. (2012)) were found to be enhanced when plasma osmolality was elevated (0-4 days). In the present study, the cortisol-injected fish had elevated glucose levels at 6 and $24 \mathrm{~h}$ (Fig. 2A), yet we found no significant difference in plasma free amino acid levels and liver transaminase activity (Fig. 2D and E). Whether this lack of effects for the common indicators of gluconeogenesis is reflective of a single acute dosage, as opposed to chronic treatment with cortisol (Vijayan et al. 1996), is unclear, as previous studies have established a clear role for cortisol in the mediation of gluconeogenesis (Van Der Boon et al. 1991, Khani \& Tayek 2001). The steroid was effective in increasing the mRNA expression of SW-type ATPase in the gill (Supplementary Fig. 3H), which is consistent with a role in the modulation of ion transport (Evans et al. 2005). Human leptin, but not homologous leptin, increased plasma free amino acid levels (Fig. 2D), but neither altered liver transaminase activity (Fig. 2E). Apart from promoting glycogenolysis, it remains inconclusive whether leptin may act in part to induce hyperglycemia through gluconeogenic pathways. Previous studies have shown that cortisol increases leptin synthesis and secretion in human adipocytes (Wabitsch et al. 1996), with leptin, in turn, suppressing the hypothalamic-pituitary-interrenal axis in both fish and humans (Szücs et al. 2001, Gorissen et al. 2012). In the present study, we demonstrated that cortisol upregulates

Published by Bioscientifica Ltd. 


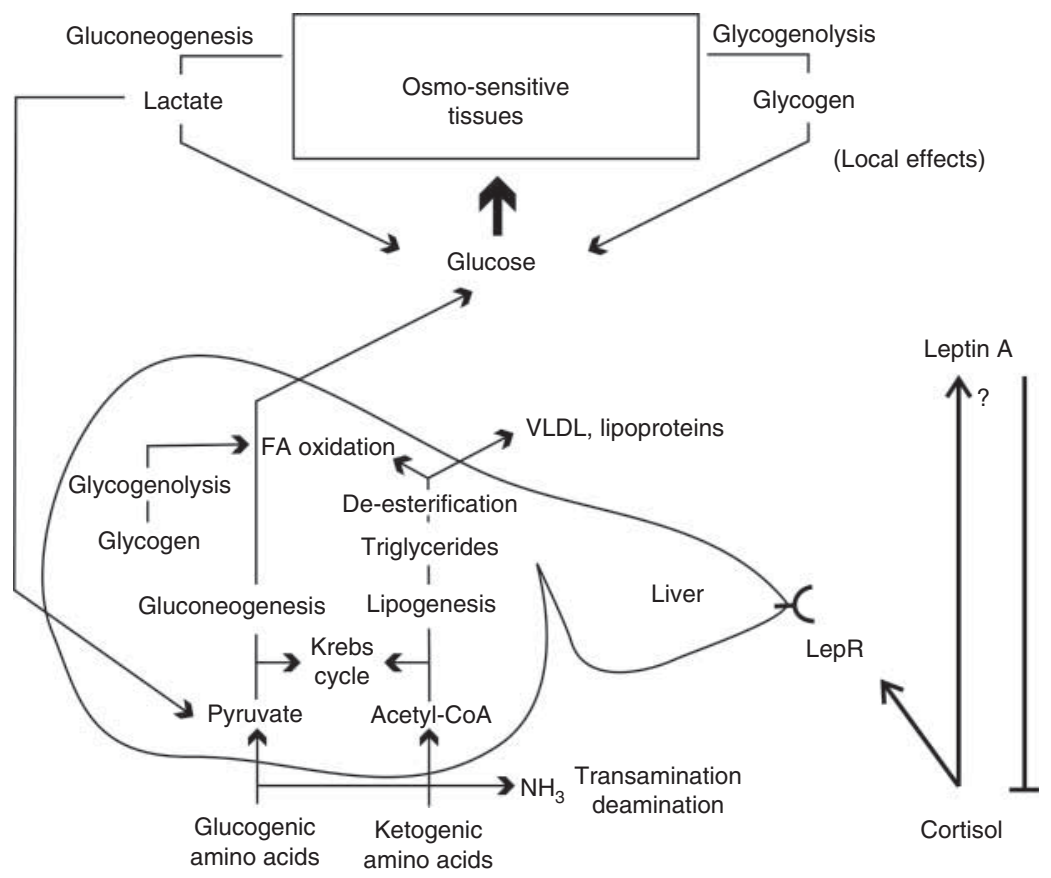

\section{Figure 4}

Bioenergetic model of hepatic energy mobilization during salinity adaptation and the regulatory interactions between leptin and cortisol. Local tissues are augmented by hepatic glycogenolysis or gluconeogenesis of glucogenic amino acids or lactate. Ketogenic amino acids are utilized by the liver or converted into triglycerides (lipogenesis). Triglycerides may be de-esterified and oxidized or exported to the blood (as lipoproteins). The

the expression of lepr in the liver of tilapia (Fig. 3D), further suggesting that these hormones are tightly linked with energy regulation in vertebrates.

In contrast to leptin, cortisol produced a 2.5 -fold increase in the mRNA expression of liver lipases ( $l p l$ and hsl; Fig. 3B and C), consistent with a known lipolytic function for this hormone (Mommsen et al. 1999), which may coincide with the increases in the expression observed during the SW challenge (Fig. $1 \mathrm{~N}$ and $\mathrm{O}$ ). This suggests that cortisol, in addition to inducing hyperglycemia, functions along with other factors (e.g. GH) in the modulation of hepatic lipolysis. The stimulation of $h s l$ mRNA expression may reflect greater rates of lipid catabolism needed for gluconeogenesis (Van Der Boon et al. 1991). This is despite elevated liver triglyceride levels being observed in SW fish, indicating that the rate of lipid accumulation exceeds that of catabolic breakdown. The enhanced accumulation could be derived, in part, from elevated lipoprotein lipase levels, which may increase fatty acid uptake in the liver (Merkel et al. 1998).

Osmoregulation is both a critical and a bioenergetically expensive component of survival in vertebrates, regulatory interactions of leptin $\mathrm{A}$ and cortisol suggest that these hormones are tightly linked to the regulation of glucose mobilization, with leptin A stimulating glycogenolysis and cortisol probably involved in gluconeogenesis of amino acids. Arrow point, stimulatory effect; bar line, inhibitory effect; and question mark, potential interaction. particularly for euryhaline fishes subjected to wide salinity fluctuations. We demonstrate that energy requirements of acute SW adaptation are principally met through the elevation of plasma glucose levels (hyperglycemia) in tilapia. Our findings suggest that two sequential mechanisms of mobilization occur following acute SW transfer, hepatic glycogenolysis, followed by potential gluconeogenesis of free amino acids. This study demonstrates for the first time that lepa mRNA is sensitive to osmotic stress and may function as a hyperglycemic factor in teleost fishes, through the induction of hepatic glycogenolysis. Although interactions of leptin with other regulators of glucose metabolism or hydromineral balance remain to be described, evidence suggests that leptin A may act in concert with cortisol to promote hyperglycemia during salinity adaptation and perhaps other catabolic processes.

\section{Supplementary data}

This is linked to the online version of the paper at http://dx.doi.org/10.1530/ JOE-13-0292. http://joe.endocrinology-journals.org DOI: $10.1530 / \mathrm{JOE}-13-0292$
(C) 2014 Society for Endocrinology Printed in Great Britain 


\section{Declaration of interest}

The authors declare that there is no conflict of interest that could be perceived as prejudicing the impartiality of the research reported.

\section{Funding}

This study was funded by USDA-NIFA (2010-34368-20940) and the AquaFish Collaborative Research Support Program of the USAID (EPP-A00-06-00012-00).

\section{Acknowledgements}

The authors thank Drs Kevin Gross and Kenneth Pollock for their discussion of statistical methods and Dr Andy McGinty (Aurora, NC, USA), Brad Ring and John Davis for the care of the fishes used in the study.

\section{References}

Aguilar AJ, Conde-Sieira M, Polakof S, Míguez JM \& Soengas JL 2010 Central leptin treatment modulates brain glucosensing function and peripheral energy metabolism of rainbow trout. Peptides 31 1044-1054. (doi:10.1016/j.peptides.2010.02.026)

Ahima RS \& Flier JS 2000 Leptin. Annual Review of Physiology 62 413-437. (doi:10.1146/annurev.physiol.62.1.413)

Aragão C, Costas B, Vargas-Chacoff L, Ruiz-Jarabo I, Dinis MT, Mancera JM \& Conceição LE 2010 Changes in plasma amino acid levels in a euryhaline fish exposed to different environmental salinities. Amino Acids 38 311-317. (doi:10.1007/s00726-009-0252-9)

Aruna A, Nagarajan G \& Chang C-F 2012 Differential expression patterns and localization of glucocorticoid and mineralocorticoid receptor transcripts in the osmoregulatory organs of tilapia during salinity stress. General and Comparative Endocrinology 179 465-476. (doi:10.1016/j.ygcen.2012.08.028)

Bashamohideen M \& Parvatheswararao V 1972 Adaptations to osmotic stress in the fresh-water euryhaline teleost Tilapia mossambica. IV. Changes in blood glucose, liver glycogen and muscle glycogen levels. Marine Biology 16 68-74. (doi:10.1007/BF00347850)

Benomar Y, Naour N, Aubourg A, Bailleux V, Gertler A, Djiane J, Guerre-Millo M \& Taouis M 2006 Insulin and leptin induce Glut4 plasma membrane translocation and glucose uptake in a human neuronal cell line by a phosphatidylinositol 3-kinase-dependent mechanism. Endocrinology 147 2550-2556. (doi:10.1210/en.2005-1464)

Bernier NJ, Gorissen M \& Flik G 2012 Differential effects of chronic hypoxia and feed restriction on the expression of leptin and its receptor, food intake regulation and the endocrine stress response in common carp. Journal of Experimental Biology 215 2273-2282. (doi:10.1242/jeb.066183)

Bouf G \& Payan P 2001 How should salinity influence fish growth? Comparative Biochemistry and Physiology. Toxicology \& Pharmacology 130 411-423. (doi:10.1016/S1532-0456(01)00268-X)

Borba-Murad GR, Vardanega-Peicher M, Galende SB, Curi R, Souza HM, Mario EG, Bassoli BK \& Bazotte RB 2004 Central role of cAMP in the inhibition of glycogen breakdown and gluconeogenesis promoted by leptin and insulin in perfused rat liver. Polish Journal of Pharmacology 56 223-231.

Borski RJ, Won ET \& Baltzegar DA 2011 Leptin stimulates hepatic growth hormone receptor expression: possible role in enhancing GH-mediated anabolic processes in fish. Conference Abstract: NASCE 2011: The inaugural meeting of the North American Society for Comparative Endocrinology Ann Arbor, USA, 13 Jul-16 Jul, 2011. Frontiers in Endocrinology. (doi:10.3389/conf.fendo.2011.04.00111)

Bustin SA 2000 Absolute quantification of mRNA using real-time reverse transcription polymerase chain reaction assays. Journal of Molecular Endocrinology 25 169-193. (doi:10.1677/jme.0.0250169)
Bystriansky JS, Frick NT \& Ballantyne JS 2007 Intermediary metabolism of Arctic char Salvelinus alpinus during short-term salinity exposure. Journal of Experimental Biology 210 1971-1985. (doi:10.1242/jeb.000059)

Chang JC, Wu SM, Tseng YC, Lee YC, Baba O \& Hwang PP 2007 Regulation of glycogen metabolism in gills and liver of the euryhaline tilapia (Oreochromis mossambicus) during acclimation to seawater. Journal of Experimental Biology 210 3494-3504. (doi:10.1242/jeb.007146)

Copeland DL, Duff RJ, Liu Q, Prokop J \& Londraville RL 2011 Leptin in teleost fishes: an argument for comparative study. Frontiers in Physiology 2 26. (doi:10.3389/fphys.2011.00026)

Crockett EL, Londraville RL, Wilkes EE \& Popesco MC 1999 Enzymatic capacities for $\beta$-oxidation of fatty fuels are low in the gill of teleost fishes despite presence of fatty acid-binding protein. Journal of Experimental Biology 284 276-285. (doi:10.1002/(SICI)1097-010X(19990801)284:3< 276::AID-JEZ5 > 3.0.CO;2-N)

Dean DB, Whitlow ZW \& Borski RJ 2003 Glucocorticoid receptor upregulation during seawater adaptation in a euryhaline teleost, the tilapia (Oreochromis mossambicus). General and Comparative Endocrinology 132 112-118. (doi:10.1016/S0016-6480(03)00053-4)

Deane EE, Kelly SP, Luk JC \& Woo NY 2002 Chronic salinity adaptation modulates hepatic heat shock protein and insulin-like growth factor I expression in black sea bream. Marine Biotechnology 4 193-205. (doi:10.1007/PL00021690)

Evans DH, Piermarini PM \& Choe KP 2005 The multifunctional fish gill: dominant site of gas exchange, osmoregulation, acid-base regulation, and excretion of nitrogenous waste. Physiological Reviews 85 97-177. (doi:10.1152/physrev.00050.2003)

Fiess JC, Kunkel-Patterson A, Mathias L, Riley LG, Yancey PH, Hirano T \& Grau EG 2007 Effects of environmental salinity and temperature on osmoregulatory ability, organic osmolytes, and plasma hormone profiles in the Mozambique tilapia (Oreochromis mossambicus). Comparative Biochemistry and Physiology. Part A, Molecular \& Integrative Physiology 146 252-264. (doi:10.1016/j.cbpa.2006.10.027)

Gorissen M, Bernier NJ, Nabuurs SB, Flik G \& Huising MO 2009 Two divergent leptin paralogues in zebrafish (Danio rerio) that originate early in teleostean evolution. Journal of Endocrinology 201 329-339. (doi:10.1677/JOE-09-0034)

Gorissen M, Bernier NJ, Manuel R, de Gelder S, Metz JR, Huising MO \& Flik G 2012 Recombinant human leptin attenuates stress axis activity in common carp (Cyprinus carpio L.). General and Comparative Endocrinology 178 75-81. (doi:10.1016/j.ygcen.2012.04.004)

Huang W, Dedousis N, Bandi A, Lopaschuk GD \& O'Doherty RM 2006 Liver triglyceride secretion and lipid oxidative metabolism are rapidly altered by leptin in vivo. Endocrinology 147 1480-1487. (doi:10.1210/en.2005-0731)

Huising MO, Geven EJW, Kruiswijk CP, Nabuurs SB, Stolte EH, Spanings FAT, Verburg-van Kemenade BML \& Flik G 2006 Increased leptin expression in common Carp (Cyprinus carpio) after food intake but not after fasting or feeding to satiation. Endocrinology 147 5786-5797. (doi:10.1210/en.20060824)

Jürss K \& Bastrop R 1995 Chapter 7: amino acid metabolism in fish. In Biochemistry and Molecular Biology of Fishes, pp 159-189. Eds PW Hochachka \& TP Mommsen. New York, NY, USA: Elsevier. (doi:10.1016/S1873-0140(06)80010-X).

Kammerer BD, Cech JJ \& Kültz D 2010 Rapid changes in plasma cortisol, osmolality, and respiration in response to salinity stress in tilapia (Oreochromis mossambicus). Comparative Biochemistry and Physiology. Part A, Molecular \& Integrative Physiology 157 260-265. (doi:10.1016/ j.cbpa.2010.07.009)

Kelley KM 1993 Experimental diabetes mellitus in a teleost fish. I. Effect of complete isletectomy and subsequent hormonal treatment on metabolism in the goby, Gillichthys mirabilis. Endocrinology 132 2689-2695. (doi:10.1210/en.132.6.2689)

Khani S \& Tayek JA 2001 Cortisol increases gluconeogenesis in humans: its role in the metabolic syndrome. Clinical Science 101 739-747. (doi:10.1042/CS20010180) 
Kurokawa T \& Murashita K 2009 Genomic characterization of multiple leptin genes and a leptin receptor gene in the Japanese medaka, Oryzias latipes. General and Comparative Endocrinology 161 229-237. (doi:10.1016/j.ygcen.2009.01.008)

Li GG, Liang XF, Xie Q, Li G, Yu Y \& Lai K 2010 Gene structure, recombinant expression and functional characterization of grass carp leptin. General and Comparative Endocrinology 166 117-127. (doi:10.1016/j.ygcen.2009.10.009)

Liu Q, Dalman M, Chen Y, Akhter M, Brahmandam S, Patel Y, Lowe J, Thakkar M, Gregory AV, Phelps D et al. 2012 Knockdown of leptin A expression dramatically alters zebrafish development. General and Comparative Endocrinology 178 562-572. (doi:10.1016/j.ygcen.2012.07.011)

Merkel M, Weinstock PH, Chajek-Shaul T, Radner H, Yin B, Breslow JL \& Goldberg IJ 1998 Lipoprotein lipase expression exclusively in liver: a mouse model for metabolism in the neonatal period and during cachexia. Journal of Clinical Investigation 102 893-901. (doi:10.1172/JCI2912)

Mommsen TP 2000 Glucagon-like peptide-1 in fishes: the liver and beyond. American Zoologist 40 259-268. (doi:10.1668/00031569(2000)040[0259:GLPIFT]2.0.CO;2)

Mommsen TP, Vijayan MM \& Moon TW 1999 Cortisol in teleosts: dynamics, mechanisms of action, and metabolic regulation. Reviews in Fish Biology and Fisheries 9 211-268. (doi:10.1023/A:1008924418720)

Morgan JD \& Iwama GK 1999 Energy cost of $\mathrm{NaCl}$ transport in isolated gills of cutthroat trout. American Journal of Physiology. Regulatory, Integrative and Comparative Physiology 277 R631-R639.

Morgan JD, Sakamoto T, Grau EG \& Iwama GK 1997 Physiological and respiratory responses of the Mozambique tilapia (Oreochromis mossambicus) to salinity acclimation. Comparative Biochemistry and Physiology. Part A, Physiology 117 391-398. (doi:10.1016/S0300-9629(96)00261-7)

Paolucci M, Buono S, Sciarrillo R \& Putti R 2006 Effects of leptin administration on the endocrine pancreas and liver in the lizard Podarcis sicula. Journal of Experimental Zoology. Part A, Comparative Experimental Biology 305 383-395. (doi:10.1002/jez.a.284)

de Pedro N, Martínez-Álvarez R \& Delgado MJ 2006 Acute and chronic leptin reduces food intake and body weight in goldfish (Carassius auratus). Journal of Endocrinology 188 513-520. (doi:10.1677/joe.1.06349)

Polakof S, Arjona FJ, Sangiao-Alvarellos S, Martín del Río MP, Mancera JM \& Soengas JL 2006 Food deprivation alters osmoregulatory and metabolic responses to salinity acclimation in Gilthead sea bream Sparus auratus. Journal of Comparative Physiology. B, Biochemical, Systematic, and Environmental Physiology 176 441-452. (doi:10.1007/s00360-006-0065-z)

Ramakers C, Ruijtera JM, LeKanne D \& Moorman AF 2003 Assumption-free analysis of quantitative real-time polymerase chain reaction (PCR) data. Neuroscience Letters 339 62-66. (doi:10.1016/S03043940(02)01423-4)

Sangiao-Alvarellos S, Arjona FJ, Martín del Río MP, Míguez JM, Mancera JM \& Soengas JL 2005 Time course of osmoregulatory and metabolic changes during osmotic acclimation in Sparus auratus. Journal of Experimental Biology 208 4291-4304. (doi:10.1242/jeb.01900)

Segner H, Dölle A \& Böhm R 1997 Ketone body metabolism in the carp Cyprinus carpio: biochemical and ${ }^{1} \mathrm{H}$ NMR spectroscopical analysis. Comparative Biochemistry and Physiology. Part B, Biochemistry and Molecular Biology 116 257-262. (doi:10.1016/S0305-0491(96)00213-1)

Shepherd BS, Sakamoto T, Nishioki RS, Richman NH III, Mori I, Madsen SS, Chen TT, Hirano T, Bern HA \& Grau EG 1997 Somatotropic actions of the homologous growth hormone and prolactins in the euryhaline teleost, the tilapia, Oreochromis mossambicus. PNAS 94 2068-2072. (doi:10.1073/pnas.94.5.2068)

Szücs N, Varga I, Jakab C, Patócs A, Gláz E, Tóth M, Kiss R \& Rácz K 2001 Leptin inhibits cortisol and corticosterone secretion in pathologic human adrenocortical cells. Pituitary 4 71-77. (doi:10.1023/ A:1012990928218)
Takekoshi K, Ishii K, Nanmoku T, Shibuya S, Kawakami Y, Isobe K \& Nakai T 2001 Leptin stimulates catecholamine synthesis in a PKC-dependent manner in cultured porcine adrenal medullary chromaffin cells. Endocrinology 142 4861-4871. (doi:10.1210/en.142.11.4861)

Tipsmark CK, Strom CN, Bailey ST \& Borski RJ 2008 Leptin stimulates pituitary prolactin release through an extracellular signal-regulated kinase-dependent pathway. Journal of Endocrinology 196 275-281. (doi:10.1677/JOE-07-0540)

Tipsmark CK, Breves JP, Seale AP, Lerner DT, Hirano T \& Grau EG 2011 Switching of $\mathrm{Na}^{+}, \mathrm{K}^{+}$-ATPase isoforms by salinity and prolactin in the gill of a cichlid fish. Journal of Endocrinology 209 237-244. (doi:10.1530/JOE-10-0495)

Trombley S, Maugars G, Kling P, Björnsson BT \& Schmitz M 2012 Effects of long-term restricted feeding on plasma leptin, hepatic leptin expression and leptin receptor expression in juvenile Atlantic salmon (Salmo salar L.). General and Comparative Endocrinology 175 92-99. (doi:10.1016/j.ygcen.2011.10.001)

Tseng YC \& Hwang PP 2008 Some insights into energy metabolism for osmoregulation in fish. Comparative Biochemistry and Physiology. Toxicology \& Pharmacology 148 419-429. (doi:10.1016/j.cbpc.2008.04.009)

Tseng YC, Huang CJ, Chang JC, Teng WY, Baba O, Fann MJ \& Hwang PP 2007 Glycogen phosphorylase in glycogen-rich cells is involved in the energy supply for ion regulation in fish gill epithelia. American Journal of Physiology. Regulatory, Integrative and Comparative Physiology 293 R482-R491. (doi:10.1152/ajpregu.00681.2006)

Van Der Boon J, Van Den Thillart GEEJM \& Addink ADF 1991 The effects of cortisol administration on intermediary metabolism in teleost fish. Comparative Biochemistry and Physiology. Part A, Physiology 100 47-53. (doi:10.1016/0300-9629(91)90182-C)

Velan A, Hulata G, Ron M \& Cnaani A 2011 Comparative time-course study on pituitary and branchial response to salinity challenge in Mozambique tilapia (Oreochromis mossambicus) and Nile tilapia (O. niloticus). Fish Physiology and Biochemistry 37 863-873. (doi:10.1007/s10695-011-9484-1)

Vijayan M, Mommsen T, Glémet HC \& Moon T 1996 Metabolic effects of cortisol treatment in a marine teleost, the sea raven. Journal of Experimental Biology 199 1509-1514.

Wabitsch M, Jensen PB, Blum WF, Christoffersen CT, Englaro P, Heinze E, Rascher W, Teller W, Tornqvist H \& Hauner H 1996 Insulin and cortisol promote leptin production in cultured human fat cells. Diabetes $\mathbf{4 5}$ 1435-1438. (doi:10.2337/diab.45.10.1435)

Wang MY, Lee Y \& Unger RH 1999 Novel form of lipolysis induced by leptin. Journal of Biological Chemistry 274 17541-17544. (doi:10.1074/ jbc.274.25.17541)

Weigle DS, Duell PB, Connor WE, Steiner RA, Soules MR \& Kuijper JL 1997 Effect of fasting, refeeding, and dietary fat restriction on plasma leptin levels. Journal of Clinical Endocrinology and Metabolism 82 561-565. (doi:10.1210/jc.82.2.561)

Won ET 2012 Cloning and characterization of leptin in a teleost fish and its role in mediating appetite and growth (Doctoral dissertation). North Carolina State University, USA, p 147 (available online from the NCSU Institutional Repository at http://www.lib.ncsu.edu/resolver/1840.16/8375).

Won ET \& Borski RJ 2013 Endocrine regulation of compensatory growth in fish. Frontiers in Endocrinology 4 74. (doi:10.3389/fendo.2013.00074)

Won ET, Baltzegar DA, Picha ME \& Borski RJ 2012 Cloning and characterization of leptin in a perciform fish, the striped bass (Morone saxatilis): control of feeding and regulation by nutritional state. General and Comparative Endocrinology 178 98-107. (doi:10.1016/j.ygcen.2012. 04.019)

Zhang H, Chen H, Zhang Y, Li S, Lu D, Zhang H, Meng Z, Liu X \& Lin H 2012 Molecular cloning, characterization and expression profiles of multiple leptin genes and a leptin receptor gene in orange-spotted grouper (Epinephelus coioides). General and Comparative Endocrinology 181 295-305. (doi:10.1016/j.ygcen.2012.09.008)

Received in final form 28 October 2013

Accepted 5 November 2013

Accepted Preprint published online 5 November 2013 http://joe.endocrinology-journals.org DOI: $10.1530 /$ JOE-13-0292
() 2014 Society for Endocrinology Printed in Great Britain 